\title{
Econometric Analysis of Stock Market Performance during COVID-19 Pandemic: A Case Study of Uzbekistan Stock Market
}

\author{
Uzbekistan Stock Market Performance during COVID-19 Pandemic
}

\author{
Mansur Eshov ${ }^{1}$, Walid Osamy ${ }^{2}$, Ahmed Aziz ${ }^{3}$, Ahmed M. Khedr ${ }^{4}$ \\ Tashkent State University of Economics, Tashkent, Uzbekistan ${ }^{1}$ \\ Computer Science Department, Faculty of Computers and Artificial intelligence, University of Benha, Egypt ${ }^{2}$ \\ Tashkent State University of Economics, Tashkent, Uzbekistan ${ }^{3}$ \\ Computer Science Department, Faculty of Computers and Artificial intelligence, University of Benha, Egypt ${ }^{3}$ \\ Computer Science Department, University of Sharjah, Sharjah 27272, $\mathrm{UAE}^{4}$
}

\begin{abstract}
This article highlights the impact of the Coronavirus disease (COVID-19). COVID-19 pandemic on the stock market of Uzbekistan on the basis of empirical research and the main factors affecting the stock market are identified as well. Secondary statistical data were collected from the Tashkent Stock Exchange, the Central Bank of the Republic of Uzbekistan, the State Statistics Committee of the Republic of Uzbekistan and other public funds, and the regression equation of the SEMmodel of the impact of the Covid-19 pandemic on the stock market of Uzbekistan was formed. In particular, indicators such as the latest daily and total number of people infected with Covid-19 in the Republic of Uzbekistan, the total number of recovered people after being infected with Covid-19, the total number of people who died of the disease, the daily number of recovered people post-infection, the stock market index of Uzbekistan, Uzbekistan Indicators such as the number of daily securities traded on the Republican Stock Exchange "Tashkent", the exchange rate of the US dollar set by the Central Bank of the Republic of Uzbekistan were selected as the main factors. The constructed regression equation was examined using F-statistics, Student's t-test, and multicorrelation tests to determine the level of adequacy. The authors identify factors based on a systematic analysis of the scientific work of world-renowned scientists on major stock markets and creates a SEM-model of the factors affecting the Uzbek stock market during the pandemic.
\end{abstract}

Keywords-Stock market; factors; SEM-model; COVID-19; global economy

\section{INTRODUCTION}

Although the COVID-19 pandemic has only recently begun, the coronavirus, a new challenge and test for humanity, has also had a strong negative impact on the economies of the world's poorest countries. Even though there is no clear evidence and proof of the biological origin of Covid-19 coronavirus, its positive and negative effects on the world economy are recognized by many scientists and publishers.

The stock market is a barometer of the economy, and the capital market reflects the general state of the country's economy to some extent. Increasing uncertainty in the stock markets leads to sharp fluctuations in prices. Under the influence of the pandemic, unprecedented changes have taken place in world stock markets. As a result, risks in the global stock market against pandemics have increased significantly, and the uncertainty of the disease and the associated economic losses have made markets highly volatile and unpredictable.

Therefore, along with other field scientists, economists have also conducted research on the impact of the pandemic on the economy, particularly the stock market. Recently, global scientists have developed various forecast scenarios on the impact of the pandemic on the stock market. Research is currently trying to answer the following questions: How can risk in stock markets respond to a pandemic? Are systemic risks increasing worldwide? What are the potential effects of policy intervention?

According to statistics, in the context of the pandemic, along with the collapse of the U.S. stock market, stock markets in Europe and Asia were also disrupted. The highest decline in global stock market indices occurred in March. The Dow Jones industrial average fell by $17.3 \%$, the S\&P 500 fell by $14.98 \%$ and the Nasdaq fell by $12.64 \%$. The Financial Times Stock Exchange Index (FTSE [19]), a key indicator of the UK stock market, fell to its worst level since 1987 in March 2020, that is by $16.99 \%$, while the stock market in Japan fell by an average of $6.4 \%$ a year [18].

During the pandemic, stock prices also fell sharply in line with indices in major stock markets. In the U.S., the market price of shares, which includes the capitalization level of all companies, fell by 33.1\%, [20] and in Europe by 39.95\%. The situation in the Pacific region was better than in the US and Europe, with a decline in the market value of shares in the region made up 26.89\% [21].

Thus, the development and implementation of scientific proposals aimed at mitigating the impact of the ongoing COVID-19 coronavirus pandemic on the economy, including the stock markets of countries around the world, is highly relevant today.

The COVID-19 crisis poses a significant risk to Uzbekistan's ambitious economic and social transition. The 
global COVID-19 pandemic is the most severe crisis Uzbekistan has faced since the economy's recovery from the breakup of the Soviet Union. It has adversely affected the domestic economy and resulted in declines in employment, well-being, and incomes. Growth is projected to slow to 1.5 percent in 2020, while lower exports and remittances are expected to widen the current account deficit to almost 10 percent of Gross domestic product (GDP). Addressing the external shock and the domestic impact of COVID-19 is expected to require additional external financing of about US\$ 4 billion (7 percent of GDP). The COVID-19 crisis has almost entirely extinguished GDP growth in 2020. To mitigate the economic, social, and health consequences of the pandemic, the Government has been taking anti-crisis policy measures. Persistent COVID-19 disruptions at the local and international levels have tempered prospects for a quick recovery in 2021. Nevertheless, Uzbekistan's outlook remains positive as reforms continue to shift the economy toward greater resource efficiency and private sector growth. This work highlight the impact of the COVID-19 (coronavirus) pandemic on the Uzbekistan stock market based on an empirical research. The main factors affecting the stock market are identified as well.

The paper is further structured as follows: Section II provides the literature review and in Section III, presents the Research methodology. The Analysis and results are included in Section IV and finally Section V concludes this research paper.

\section{LITERATURE REVIEW}

The outbreak of the COVID-19 pandemic in the world has had a negative impact on the global economy, leading to a sudden cessation of supply and demand for a period of time, with industrial enterprises, most service sectors and a large proportion of small businesses stalling for some time. This, in turn, has negatively affected major stock markets such as the Dow Jones, Nasdaq, S\&P 500. A number of scientific studies have been conducted by the world community of scientists to study these problems.

The impact of various infections, epidemics and pandemics on the global economy in the 21st century has been studied by [7]. (2020), and the laws governing the impact of pandemics on the economy have been identified.

In his study, [11] examined the reaction of stock markets to the COVID-19 pandemic. According to the author, the growth of confirmed COVID-19 cases had a negative impact on stock markets, using data on daily COVID-19 approved cases and deaths, and data on stock market earnings from 64 countries from 22 January 2020 to 17 April 2020. That is, as the number of approved cases increases, the profitability of the stock market decreases. The author also notes that stock markets have a greater impact on the increase in confirmed cases than deaths [11].

The team of authors in [12] studied the impact of COVID19 on the Indian financial market and compared it with the results of the last two structural changes in the country's economy: demonetization and goods and services introduction of the goods and services tax (GST). Daily stock yields from January 3, 2003 to April 20, 2020 will be negative for all indices during the COVID-19 spread, in contrast to the postdemonetization and post-GST phases based on net foreign institutional investors and exchange rate [17] data. According to the study, the COVID-19 pandemic will have a significant impact on stock yields relative to demonetization and GST performance in India. Foreign researchers Kerstin Lopatta, Kenji Alexander, Laura Gastone and Thomas [13] used data from nearly 300 international companies included in the leading stock market indices of ten countries to report on companies 'reporting practices during the COVID-19 coronavirus pandemic studied the impact on capital values and the assessment of capital market risks. The authors draw two main conclusions from the research findings. First, it was found that beta-value declines in the annual reports of firms reporting the coronavirus crisis using the capital market model.

Second, comparing the earnings before and after the publication of the annual report, it was found that the earnings of firms that report coronavirus pandemics in their annual reports have improved significantly. The authors 'research shows that investors value the transparency of information about companies and their ability to promptly make global changes in the reporting process. Spanish researchers have studied market variability (volatility) and stock market comparisons during the COVID-19 pandemic and formed a number of conclusions. In particular, you should not buy or sell based on news or daily market movements. Fear, speculation and uncertainty increase volatility in the market [15][16].

The impact of the Covid-19 pandemic on the stock market in the United States and the problems of its integral link with geopolitical and political uncertainties have been studied by Arshian Sharifa, Chaker Aloui, Larisa [1].

The influence of the stock market reaction to the pandemic in the first quarter of the onset of the Covid-19 pandemic was analyzed by a number of scientists [2] preliminary results were obtained [4-5]. These studies have shown an increase in the share prices of food companies and IT software companies (Zoom, Yandex, Vine, etc.) in the stock market.

Complex changes in the stock market, changes in the economies of the U.S. and European countries, according to the statements of the World Health Organization and the conclusions on the COVID-19 and studied in depth by other scholars [6-8].

Based on the recommendations of medical scientists on face and hand masks, the popularity of cashless payments has led to an increase in the price of digital money such as Bitcoin in the world and its impact on the stock market has been studied by [3].

The work in [9] studied the stock markets of 12 countries with high liquidity and proved that people's panic increases market risk and negatively affects stock prices.

Recent research by [10] has shown that the use of gold in stock market risk hedging is advisable. In the complex changes of the stock market at different time intervals of the pademy, it was found that only the stability of gold is an acceptable tool in preventing financial risks. 
The analysis of the above literature shows that the impact of the Covid-19 coronavirus pandemic on the stock markets, which is one of the most important financial institutions in developed and rapidly developing countries, has been thoroughly studied. This, in turn, indicates that stock markets make a significant contribution to the economic development of these countries. However, Uzbek economists have not yet done enough research on the impact of the pandemic on the Uzbekistan stock market.

\section{RESEARCH METHODOLOGY}

In the course of the study, the direct and indirect factors affecting the stock market were selected, the relationship between them was made on the basis of correlation analysis, and the regression equation based on the Structural equation Model (SEM-model) of the impact of the Covid-19 pandemic on the Uzbek stock market. Secondary statistics for the econometric model were collected from the Tashkent Stock Exchange, the Central Bank of the Republic of Uzbekistan, the State Statistics Committee of the Republic of Uzbekistan and other open sources.

\section{ANALYSIS AND RESUlts}

In late December 2019, China officially reported to the World Health Organization that a coronavirus infection COVID-19 caused by an unknown type of pneumonia had occurred in Wuhan Province. The virus was detected to be transmitted from person to person, and there was no cure for it when the epidemic began.

In January 2020, the first cases appeared outside of China. On March 13, the number of cases exceeded 132,000, with 4,947 deaths, compared to 123 in the countries where the virus was detected.

Against the backdrop of a new disease outbreak, investors have reconsidered their views on the future of the global economy. Restrictive measures introduced in different countries have negatively affected almost all sectors related to consumer activities: tourism, trade, catering, entertainment and others. Under quarantine, people spend less money and move on.

Traders began to get rid of shares of airlines, oil companies, home appliance manufacturers and other companies in anticipation of declining profits and earnings. Indices of the world's leading stock exchanges fell. Italy's FTSE market index for the Borsa Italiana (MIB) index alone lost 29.8\% from February 19 to March 11. Interestingly, the Chinese stock market began to recover slowly, while in other countries it continued to decline.

The COVID-19 coronavirus affects 218 countries and territories around the world and 2 international vehicles. The list of countries and regions and their continental regional classification is based on the United Nations Geoscheme [14] (Table I).

Asian stock exchanges have suffered the most from the coronavirus. In particular, the KOSPI 200 index, which consists of shares of the 200 largest companies in South Korea, fell to a 10-year low.
European stock exchanges in France, the United Kingdom and Germany also suffered from the effects of the coronavirus pandemic.

Measures are being taken around the world to mitigate the effects of the coronavirus pandemic. A number of programs are being developed and implemented to stabilize the impact of the coronavirus pandemic on the global economy and financial markets.

Many countries have already suffered from supply chain disruptions as China is a supplier of many types of components, including electronics, automotive, machinery and various equipments for such industries.

As for Uzbekistan, according to 2019 data, it is in the structure of imports. China is the largest partner ( $\$ 5.1$ billion), followed by Russia (\$ 4.1 billion) and Korea (\$ 2.6 billion). It is important to pay attention to the composition of imports China and Korea are the main suppliers of machinery and equipment to Uzbekistan, supplying about $50 \%$ of the total.

According to the Central Bank of Uzbekistan for 9 months of 2019, remittances (personal remittances) to the Republic of Uzbekistan amounted to 4.5 billion US dollars, of which $85 \%$ from Russia and 6\% from Kazakhstan. While maintaining current energy prices, remittances to Uzbekistan expect to fall by $15-20$ percent in 2020 . In times of crisis, investors begin to sell valuable assets such as securities and invest in defense assets. Protective assets include U.S. government bonds and gold.

This could be a positive result, given that Uzbekistan exported \$ 4.9 billion worth of gold, or 27.5 percent of total exports. While maintaining the current price range for 2020 and the volume of exports in tons, this figure could exceed $25 \%$.

In the econometric analysis of the factors affecting the development of the stock market of Uzbekistan COVID-19 coronavirus pandemic, first of all, it is necessary to choose the theoretically and logically correct factors. To study the impact of the Covid-19 coronavirus pandemic on the development of the Uzbek stock market the following is considered (Fig. 1):

1) The daily turnover of the Covid-19 coronavirus infection in the Republic of Uzbekistan - x1,

2) Total number of patients-x2,

3) Total number of patients with coronavirus Covid-19 in the Republic of Uzbekistan -x3,

4) Total number of deaths from coronavirus infection in the Republic of Uzbekistan - $\mathrm{x} 4$,

5) Days of recovery from coronavirus infection in the Republic of Uzbekistan Covid-19 -x5,

6) Stock Market Index of the Republic of Uzbekistan -x6,

7) Number of daily securities traded on the Republican Stock Exchange "Tashkent" of the Republic of Uzbekistan -x7,

8) US dollar exchange rate set by the Central Bank of the Republic of Uzbekistan -x8. Statistics on the number of cases, cures and deaths of Covid-19 coronavirus infection in the Republic of Uzbekistan are available on the official website [15]. 
Based on the selected factors, it is expedient to determine their degree of correlation by means of a correlation coefficient in a special program Stata 16 (Table II).

If the descriptive statistics examined of the sample, it noticed that the number of observations is 181 and the factors are 8 , and the mean deviations and boundary values are shown in Table IV.
According to the table, there is a strong correlation between the resulting factor and the selected factors, and since the correlation between the factors is dense and the conditions $\mid \mathrm{r}$ $\left(\left[x_{-}(1),\right] \_2\right) \mid<0.8$, there is no multicollinearity between the factors and regression equation can be constructed. The regression equation shows what functional relationship exists between the resulting factor and the selected factors (Table III).

TABLE I. WORLD COVID-19 CORONAVIRUS INFORMATION AS OF DECEMBER 10, 2020 (2020)

\begin{tabular}{|c|c|c|c|c|c|c|c|c|c|c|c|c|c|}
\hline № & $\begin{array}{l}\text { Country, } \\
\text { Other }\end{array}$ & $\begin{array}{l}\text { Total } \\
\text { Cases }\end{array}$ & $\begin{array}{l}\text { New } \\
\text { Cases }\end{array}$ & $\begin{array}{l}\text { Total } \\
\text { Deaths }\end{array}$ & $\begin{array}{l}\text { New } \\
\text { Death } \\
s\end{array}$ & $\begin{array}{l}\text { Total } \\
\text { Recovere } \\
\text { d }\end{array}$ & $\begin{array}{l}\text { Active } \\
\text { Cases }\end{array}$ & $\begin{array}{l}\text { Serious } \\
\text { Critical }\end{array}$ & $\begin{array}{l}\text { Tot } \\
\text { Cases/ } \\
\text { 1Mpo } \\
\text { p }\end{array}$ & $\begin{array}{l}\text { Deaths/1 } \\
\text { M pop }\end{array}$ & $\begin{array}{l}\text { Total } \\
\text { Tests }\end{array}$ & $\begin{array}{l}\text { Tests/ } \\
\text { 1M pop }\end{array}$ & Population \\
\hline & World & $\begin{array}{l}69,332,09 \\
4\end{array}$ & 116.481 & $\begin{array}{l}1,577,77 \\
7\end{array}$ & 2.885 & $\begin{array}{l}48,088,70 \\
4\end{array}$ & $\begin{array}{l}19,665,61 \\
3\end{array}$ & 106.846 & 8.895 & 202.4 & & & \\
\hline 1 & USA & $\begin{array}{l}15,822,73 \\
4\end{array}$ & $+1,371$ & 296.745 & +30 & $9,231,811$ & $6,294,178$ & 27.329 & 47.679 & 894 & $\begin{array}{l}231,115,48 \\
8\end{array}$ & 642.185 & $331,859,797$ \\
\hline 2 & India & $9,767,371$ & $+5,045$ & 141.772 & +37 & $9,253,306$ & 372.293 & 8.944 & 7.047 & 102 & $\begin{array}{l}150,759,72 \\
6\end{array}$ & 108.775 & $\begin{array}{l}1,385,975,03 \\
5\end{array}$ \\
\hline 3 & Brazil & $6,730,118$ & & 179.032 & & $5,901,511$ & 649.575 & 8.318 & 31.563 & 840 & $25,700,000$ & 120.529 & $213,225,942$ \\
\hline 4 & Russia & $2,569,126$ & $\begin{array}{l}+27,92 \\
7\end{array}$ & 45.28 & +562 & $2,033,669$ & 490.177 & 2.3 & 17.601 & 310 & $81,021,364$ & 555.084 & $145,962,223$ \\
\hline 5 & France & $2,324,216$ & & 56.648 & & 173.247 & $2,094,321$ & 3.041 & 35.572 & 867 & $28,023,593$ & 428.905 & $65,337,492$ \\
\hline 6 & Italy & $1,770,149$ & & 61.739 & & 997.895 & 710.515 & 3.32 & 29.296 & 1.022 & $23,504,588$ & 389.005 & $60,422,323$ \\
\hline 7 & UK & $1,766,819$ & & 62.566 & & N/A & N/A & 1.272 & 25.966 & 919 & $46,344,703$ & 681.103 & $68,043,572$ \\
\hline 8 & Spain & $1,725,473$ & & 47.019 & & $N / A$ & N/A & 2.179 & 36.898 & 1.005 & $24,101,272$ & 515.394 & $46,762,812$ \\
\hline 9 & Argentina & $1,475,222$ & & 40.222 & & $1,311,488$ & 123.512 & 3.688 & 32.509 & 886 & $4,145,226$ & 91.348 & $45,378,388$ \\
\hline 10 & Colombia & $1,392,133$ & & 38.308 & & $1,287,597$ & 66.228 & 2.376 & 27.232 & 749 & $6,855,035$ & 134.093 & $51,121,380$ \\
\hline 11 & Germany & $1,242,253$ & & 20.704 & & 902,100 & 319.449 & 4.278 & 14.806 & 247 & $30,494,036$ & 363.446 & $83,902,518$ \\
\hline 12 & Mexico & $1,205,229$ & $\begin{array}{l}+11,97 \\
4\end{array}$ & 111.655 & +781 & 889.168 & 204.406 & 3.515 & 9.305 & 862 & $3,086,510$ & 23.829 & $129,528,514$ \\
\hline 13 & Poland & $1,102,096$ & $\begin{array}{l}+13,74 \\
9 \\
\end{array}$ & 21,630 & +470 & 792.119 & 288.347 & 1.775 & 29.134 & 572 & $6,586,361$ & 174.112 & $37,828,199$ \\
\hline \multicolumn{14}{|l|}{$\ldots$} \\
\hline 76 & Libya & 89.183 & +661 & 1.273 & +12 & 59,222 & 28,688 & & 12,902 & 184 & 474,223 & 68,606 & $6,912,270$ \\
\hline 77 & Bahrain & 88.495 & & 347 & & 86,518 & 1,630 & 6 & 51,243 & 201 & $2,149,366$ & $\begin{array}{l}1,244,57 \\
8\end{array}$ & $1,726,984$ \\
\hline 78 & China & 86.673 & +12 & 4.634 & & 81,754 & 285 & 5 & 60 & 3 & $\begin{array}{l}160,000,00 \\
0\end{array}$ & 111,163 & $\begin{array}{l}1,439,323,77 \\
6\end{array}$ \\
\hline 79 & Lithuania & 83.883 & $+3,330$ & 735 & +31 & 34,975 & 48,173 & 173 & 31,008 & 272 & $1,372,990$ & 507,529 & $2,705,247$ \\
\hline 80 & $\begin{array}{l}\text { Kyrgyzsta } \\
\text { n }\end{array}$ & 76.391 & +379 & 1.306 & +3 & 68,894 & 6,191 & 106 & 11,625 & 199 & 533,736 & 81,223 & $6,571,274$ \\
\hline 81 & Malaysia & 76.265 & & 393 & & 65,124 & 10,748 & 127 & 2,343 & 12 & $2,851,220$ & 87,600 & $32,547,996$ \\
\hline 82 & Ireland & 74,900 & & 2.102 & & 23,364 & 49,434 & 38 & 15,095 & 424 & $2,063,450$ & 415,848 & $4,962,029$ \\
\hline 83 & $\begin{array}{l}\text { Uzbekista } \\
\text { n }\end{array}$ & 74.498 & +146 & 611 & & 71,740 & 2,147 & 179 & 2,212 & 18 & $1,377,915$ & 40,910 & $33,681,756$ \\
\hline
\end{tabular}

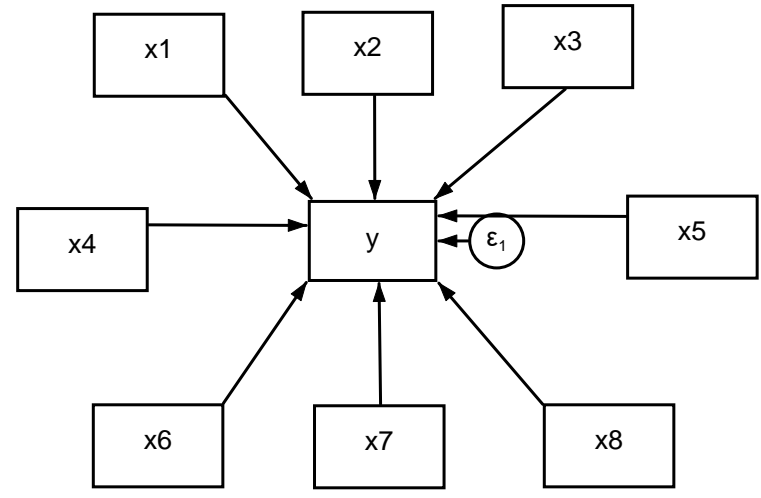

Fig. 1. Conceptual view of the Multifactorial SEM-model of the Impact of the Covid-19 Coronavirus Pandemic on the Development of the Stock Market in the Republic of Uzbekistan. 


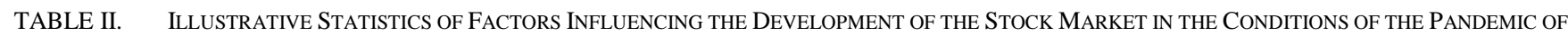
COVID-19 VIRUS IN THE REPUBLIC OF UZBEKISTAN

\begin{tabular}{|c|l|l|c|}
\hline \multirow{2}{*}{ Variable Name } & Vars: 9 & Dariable Label \\
\cline { 2 - 4 } & Storage Type & $\% 8.0 \mathrm{~g}$ & $y$ \\
\hline$X_{1}$ & float & $\% 8.0 \mathrm{~g}$ & $X_{1}$ \\
\hline$X_{2}$ & long & $\% 8.0 \mathrm{~g}$ & $X_{2}$ \\
\hline$X_{3}$ & int & $\% 8.0 \mathrm{~g}$ & $X_{3}$ \\
\hline$X_{4}$ & long & $\% 8.0 \mathrm{~g}$ & $X_{4}$ \\
\hline$X_{5}$ & int & $\% 8.0 \mathrm{~g}$ & $X_{5}$ \\
\hline$X_{6}$ & int & $\% 8.0 \mathrm{~g}$ & $X_{6}$ \\
\hline$X_{7}$ & float & $\% 8.0 \mathrm{~g}$ & $X_{7}$ \\
\hline$X_{8}$ & long & $\% 8.0 \mathrm{~g}$ & $X_{8}$ \\
\hline
\end{tabular}

TABLE III. STANDARD DEVIATION VALUES OF FACTORS INFLUENCING THE DEVELOPMENT OF THE STOCK MARKET IN THE CONDITIONS OF THE PANDEMIC OF COVID-19 VIRUS IN THE REPUBLIC OF UZBEKISTAN

\begin{tabular}{|c|l|l|l|l|l|}
\hline Variable & obs & mean & Std.Dev. & min & $\max$ \\
\hline$y$ & 181 & 430343.9 & 1055343 & 1703.7 & 6857460 \\
\hline$X_{1}$ & 181 & 28024.02 & 26597.18 & 8 & 73094 \\
\hline$X_{2}$ & 181 & 368.3094 & 428.1241 & 3 & 3030 \\
\hline$X_{3}$ & 181 & 25223.78 & 25955.46 & 0 & 70337 \\
\hline$X_{4}$ & 181 & 216.3039 & 229.979 & 0 & 610 \\
\hline$X_{5}$ & 181 & 371.9834 & 524.7122 & 0 & 3582 \\
\hline$X_{6}$ & 181 & 622.8969 & 10.2359 & 598.56 & 647.08 \\
\hline$X_{7}$ & 181 & 2243300 & $1.34 \mathrm{e}+07$ & 5533 & $1.75 \mathrm{e}+08$ \\
\hline$X_{8}$ & 181 & 10325.6 & 1301.471 & 9520.3 & 20225 \\
\hline
\end{tabular}

TABLE IV. CORRELATION ANALYSIS OF THE IMPACT OF THE COVID-19 VIRUS PANDEMIC ON THE DEVELOPMENT OF THE STOCK MARKET IN THE REPUBLIC OF UZBEKISTAN

\begin{tabular}{|c|l|l|l|l|l|l|l|}
\hline Variable & \multicolumn{1}{|c|}{$\boldsymbol{X}_{\mathbf{1}}$} & \multicolumn{1}{c|}{$\boldsymbol{X}_{\mathbf{2}}$} & \multicolumn{1}{c|}{$\boldsymbol{X}_{\mathbf{3}}$} & \multicolumn{1}{c|}{$\boldsymbol{X}_{\mathbf{4}}$} & \multicolumn{1}{c|}{$\boldsymbol{X}_{\mathbf{5}}$} & \multicolumn{1}{c|}{$\boldsymbol{X}_{\mathbf{6}}$} & $\boldsymbol{X}_{\mathbf{7}}$ \\
\hline$X_{1}$ & 1.0000 & - & - & - & - & - & - \\
\hline$X_{2}$ & 0.3714 & 1.000 & & & & & \\
\hline$X_{3}$ & 0.9963 & 0.3245 & 1.000 & & & & \\
\hline$X_{4}$ & 0.9956 & 0.3229 & 0.9987 & 1.0000 & & & \\
\hline$X_{5}$ & 0.3640 & 0.9397 & 0.3241 & 0.3171 & 1.000 & & \\
\hline$X_{6}$ & 0.1944 & 0.2074 & 0.1514 & 0.1357 & 0.1920 & 1.000 & \\
\hline$X_{7}$ & 0.0746 & 0.0123 & 0.0775 & 0.0761 & -0.0066 & -0.014 & 1.000 \\
\hline$X_{8}$ & 0.1106 & 0.2800 & 0.0761 & 0.0830 & 0.2558 & 0.2195 & 0.0078 \\
\hline
\end{tabular}

It is advisable to use the modern Stata 14 or Eviews program to construct the regression equation.

According to Table III, the significance of the correlation should be examined against certain criteria. For example, the new daily number of Covid-19 coronavirus infections in the Republic of Uzbekistan is closely related to the total number of Covid-19 coronavirus deaths in the Republic of Uzbekistan (| r _ $\left(\left[\mathrm{x}_{-}\left(1, \mathrm{x}_{\text {- }} \mathrm{C}_{4}\right) \mid=0,9956\right)\right.$, in fact, it is logical that the number of deaths due to the disease is directly related to the number of people suffering from the disease. A similar situation is closely related to the total number of coronavirus infections in the Republic of Uzbekistan $\left(\left|\mathrm{r}_{-}\left(\left[\mathrm{x}_{-}(5,) \mathrm{x}\right] \_2\right)\right|\right.$ $=0.9397)$. However, there is a strong correlation between the

total number of people cured of Covid-19 coronavirus infection in the Republic of Uzbekistan -X_3 and the total number of deaths from Covid-19 coronavirus infection in the Republic of Uzbekistan -X_4, which requires the exclusion of one of these factors.

To test the hypothesis that the development of the stock market in the Republic of Uzbekistan is affected by the Covid19 coronavirus pandemic, a regression model is constructed between immutable and unchanging.

A regression matrix was obtained on the basis of a twofactor SEM-model of the impact of the Covid-19 coronavirus pandemic on the development of the stock market in the Republic of Uzbekistan (Table V). 


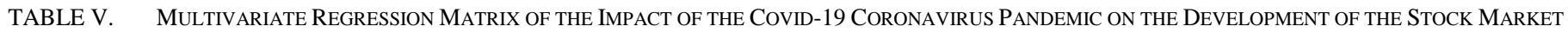
IN THE REPUBLIC OF UZBEKISTAN

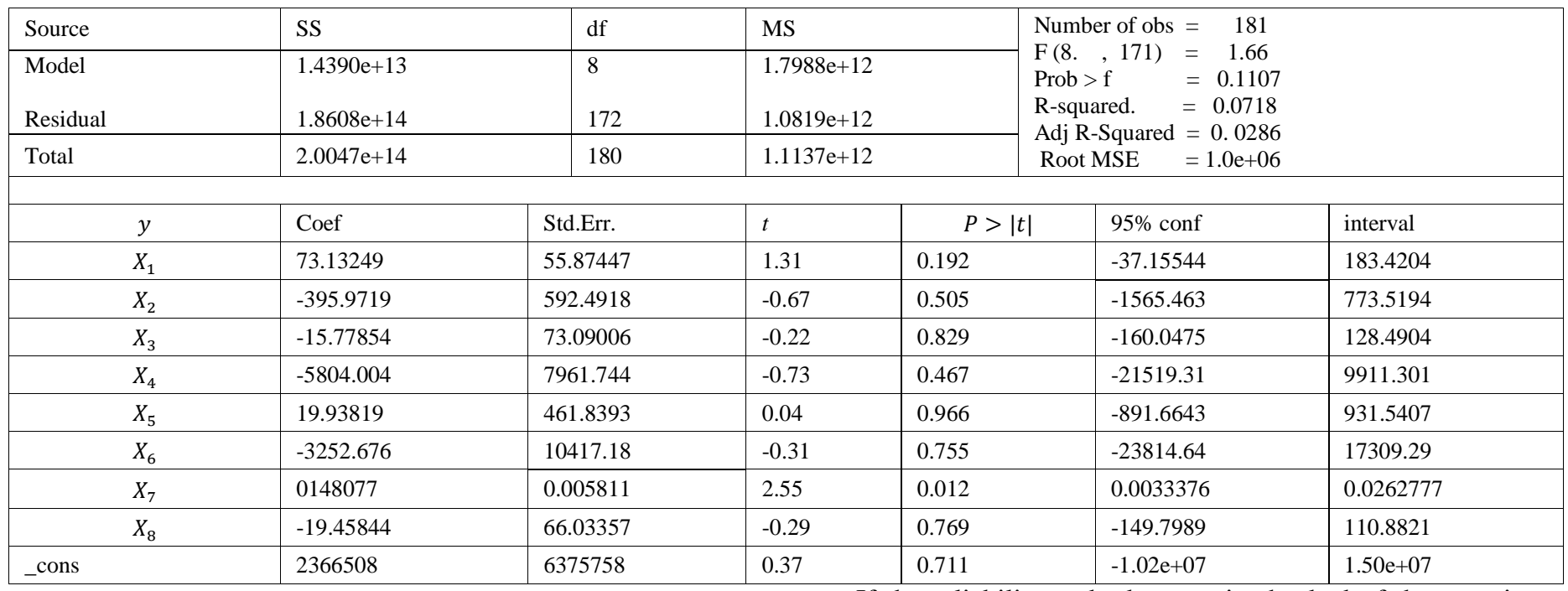

The reliability and adequacy of the regression equation should be checked against the criteria. The inspection was performed using the Stata 14 program. The Fisher criterion is F_stat $=0.11$, which is greater than 0.05 , which means that the model is not statistically significant. The p-value of each factor in the regression equation of factors $\mathrm{x} 1, \mathrm{x} 2, \mathrm{x} 3, \mathrm{x} 4, \mathrm{x} 5, \mathrm{x} 6$, and $\mathrm{x} 8$ is $0.19,0.50,0.82,0.46 .0 .96 .0 .75 .0 .76$, respectively, and no factor other than $\mathrm{x} 7$ does not matter.

According to the table, there is a strong correlation between the resulting factor and the selected factors, and since the correlation between the factors is dense and the conditions $\mid \mathrm{r}_{-}$ $\left(\left[x_{-}(1,) x_{2}{ }_{2}\right) \mid<0.8\right.$-salt of the regression equation on the basis of the model, the functional relationship is studied between the resultant factor of the regression equation and the selected factors (Table VI).

TABLE VI. DOUBLE CORRELATION OF FACTORS INFLUENCING THE DEVELOPMENT OF THE STOCK MARKET IN THE CONDITIONS OF THE PANDEMIC OF COVID-19 VIRUS IN THE REPUBLIC OF UZBEKISTAN

\begin{tabular}{|l|l|l|}
\cline { 2 - 3 } \multicolumn{1}{c|}{} & $\mathrm{x} 3$ & $\mathrm{x} 7$ \\
\hline $\mathrm{x} 3$ & 1.0000 & 0.0775 \\
\hline $\mathrm{x} 7$ & 0.2999 & 1.0000 \\
\hline
\end{tabular}

The regression matrix was obtained on the basis of a twofactor SEM model of the impact of the Covid-19 coronavirus pandemic on the development of the stock market in the Republic of Uzbekistan in Fig. 2 (Table VII).

$Y=264240,1+5,27 \cdot X_{-} 3+0,14 \cdot X_{-} 7$

Here:

$\mathrm{Y}$ - volume of daily trade turnover on the stock exchange of the Republic of Tashkent;

x3 is the total number of people who have recovered from Covid-19 coronavirus infection in the Republic of Uzbekistan.

x7 - The number of daily securities traded on the Republican Stock Exchange "Tashkent" of the Republic of Uzbekistan.
If the reliability and adequacy is checked of the equation, the Fisher criterion is F_stat $=0.006$, which is less than 0.05 , which means that the model is statistically significant. The pvalue of each factor in the regression equation of factors $\mathrm{x} 3$ and $\mathrm{x} 7$ is 0.078 and 0.011 , respectively, and at 0.1 both factors are significant.

However, the coefficient of determination is $\mathrm{R}=0.055$, which can explain only 5 percent of the total set. It can be concluded that in the context of the Covid-19 coronavirus pandemic, there are other factors that affect the daily turnover of the Republican Stock Exchange "Tashkent".

In conclusion, the increase in the number of people cured of Covid-19 coronavirus infection in the Republic of Uzbekistan by one unit will increase the daily turnover of the Republican Stock Exchange "Tashkent" by 5.27 units. An increase in the number of daily securities traded on the Republican Stock Exchange "Tashkent" of the Republic of Uzbekistan will increase the volume of daily turnover on the Republican Stock Exchange "Tashkent" by 0.005 units.

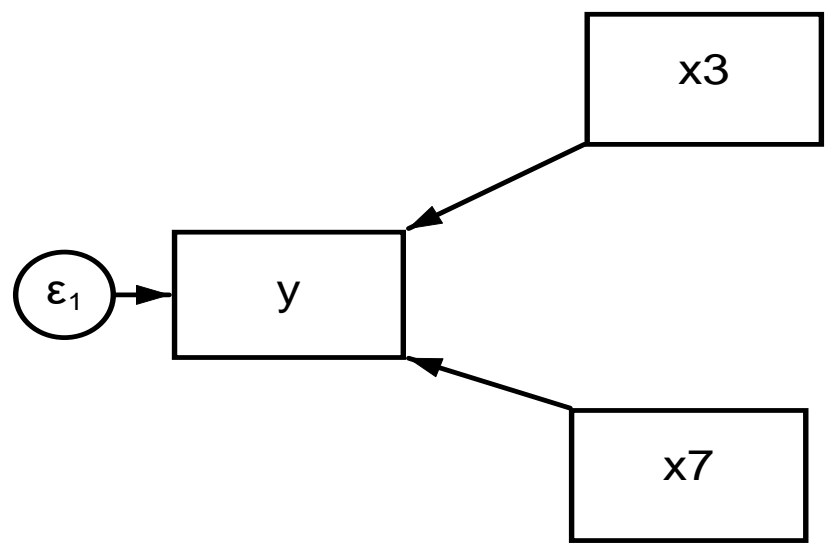

Fig. 2. Two-Factor SEM-Model of the Impact of the Covid-19 Coronavirus Pandemic on the Development of the Stock Market in the Republic of Uzbekistan. 
TABLE VII. TwO-FACTOR REgression MAtrix OF THE IMPACT OF THE COVID-19 CORONAVIRUs PANDEMIC ON THE DEVELOPMENT OF THE STOCK MARKET IN THE REPUBLIC OF UZBEKISTAN

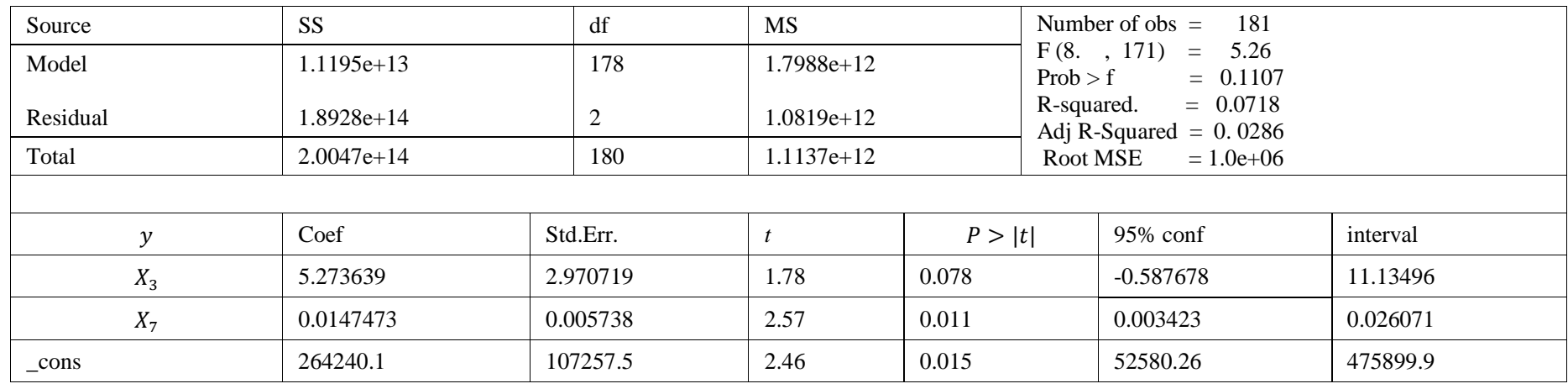

V. CONCLUSIONS AND SUGGESTIONS

The increase in the number of Covid-19 coronavirus infections in the Republic of Uzbekistan will lead to an increase in stock market turnover. This is because the increase in the number of people cured of the virus leads to an increase in the number of securities, resulting in an acceleration of socio-economic activity in the general population.

While Spanish researchers found that fear and uncertainty in the stock market during the Covid-19 coronavirus pandemic increased market volatility, our empirical study showed that fear and uncertainty in the Covid-19 coronavirus pandemic in developing countries weakened stock market activation.

According to the multivariate SEM model of the impact of the Covid-19 coronavirus pandemic on the development of the stock market in the Republic of Uzbekistan, the daily turnover of the country's stock exchange did not significantly affect the number of people infected, cured and died of Covid-19 coronavirus infection.

This means that the development of the Uzbek stock market is lower than in other Asian stock markets. During the Covid-19 coronavirus pandemic in the Asian, European and US stock markets, the price of shares in pharmaceuticals, IT programs and sales of companies in this field increased sharply. Therefore, it is necessary to emphasize the introduction of modern IT technologies in the stock market of Uzbekistan.

In order to accelerate the effective functioning of the stock market in Uzbekistan, it is necessary to assist in expanding the activities of investment companies, consulting firms, management companies, nominal depositors and underwriters.

\section{AbBreviations}

GST: The goods and services tax.

COVID-19: Coronavirus disease.

FTSE: The Financial Times Stock Exchange Index.

GDP: Gross domestic product.

MIB: Market index for the Borsa.

SEM-model: Structural equation Model.
ACKNOWLEDGMENTS

The views and opinions expressed in this paper are solely those of the author and are not necessarily those of the State Secretariat for Economic Affairs. We would thank Prof. Dilshodjon for his support and invaluable advice.

\section{AUTHOR'S CONTRIBUTIONS}

The author(s) read and approved the final manuscript.

FUNDING

None.

\section{AVAILABILITY OF DATA AND MATERIALS}

The datasets used and/or analyzed during the current study are available from the corresponding author on reasonable request.

\section{REFERENCES}

[1] Arshian Sharifa, Chaker Aloui, Larisa Yarovay (2020). COVID-19 pandemic, oil prices, stock market, geopolitical risk and policy uncertainty nexus in the US economy: Fresh evidence from the wavelet based approach. International Review of Financial Analysis, Vol.70, pp.1-9.

[2] Baker, S. R., Bloom, N., Davis, S. J., Kost, K., Sammon, M., \& Viratyosinm, T. (2020). The unprecedented stock market reaction to COVID-19. Available on the link https:// www.policyuncertainty.com/media/StockMarkets_COVID.pdf-24-032020.

[3] Conlon, T., McGee, R. (2020) Safe haven or risky hazard? Bitcoin during the COVID-19 bear market (March 24, 2020). Available at SSRN: https://doi.org/10.2139/ssrn.3560361.

[4] Corbet et al. (2020a) Corbet, S., Hou, G., Yang, H., Lucey, B. M., Les, O. (2020). Aye Corona! The contagion effects of being named corona during the COVID-19 pandemic (March 26, 2020). Available at https://doi.org/10.2139/ssm.3561866.

[5] Correia, S., Luck, S., \& Verner, E. (2020). Pandemics depress the economy. Public health interventions do not: Evidence from the 1918 flu. Tech. rep. https://doi.org/10.2139/ssrn.3561560.

[6] Harvey, A. C. (2020). The economic and financial implications of COVID-19 (3rd April, 2020). the Mayo Center for Asset Management at the University of Virginia Darden School of Business and the Financial Management Association International virtual seminars series. https://www.darden.virginia.edu/mayo-center/events/virtualspeakerseries.

[7] Ma, C., Rogers, J. H., \& Zhou, S. (2020). Global economic and financial effects of 21st century pandemics and epidemics. Paper available on the link https://papers.ssrncom/sol3/papers.cfm?abstract_id=3565646. 
[8] Wu, K. J. Z., Xu, M., \& Yang, L. (2020). Can crude oil drive the comovement in the international stock market? Evidence from the partial wavelet coherence analysis. The North American Journal of Economics and Finance, 53, 101-119.

[9] Shobhit Aggarwal, Samarpan Nawn, Amish Dugar (2020). What caused global stock market meltdown during the COVID pandemic-Lockdown stringency or investor panic? Finance Research Letters. November`2, pp.56-67. https://doi.org/10.1016/j.frl.2020.101827.

[10] Oluwasegun B. Adekoya, Johnson A. Oliyide, Gabriel O. Oduyemi (2020). How COVID-19 upturns the hedging potentials of gold against oil and stock markets risks: Nonlinear evidences through threshold regression and markov-regime switching models. Resources Policy. November 9, pp.32-41. https://doi.org/10.1016/j.resourpol.2020.101926.

[11] Badar Nadeem Ashraf. Stock markets' reaction to COVID-19: Cases or fatalities? // Research in International Business and Finance 54 (2020) 101249. (https://doi.org/10.1016/j.ribaf.2020.101249).

[12] Alok Kumar Mishra, Badri Narayan Rath, and Aruna Kumar Dash. Does the Indian Financial Market Nosedive because of the COVID-19.
[13] Outbreak, in Comparison to after Demonetisation and the GST? // Emerging markets finance and trade. 2020, Vol. 56, No. 10, 2162-2180. (https://doi.org/10.1080/1540496X.2020.1785425).

[14] Lopatta, Kerstin and Alexander, Ernst-Kenji and Gastone, Laura Maria and Tammen, Thomas. To Report or Not to Report About Coronavirus? The Role of Periodic Reporting in Explaining Capital Market Reactions During the COVID-19 Pandemic (April 3, 2020). Available at: http://dx.doi.org/10.2139/ssrn.3567778.

[15] https://www.worldometers.info/coronavirus/ (2020).

[16] https://coronavirus.uz/ru (2020).

[17] https://uza.uz/oz/business/dunye-davlatlari-i-tisodi-koronavirusdan-aydarazhada-zarar--27-03-2020.

[18] https://nbu.uz/exchange-rates (2020).

[19] https://ru.investing.com; (2020).

[20] https://www.ftserussell.com (2020).

[21] https://www.bloomberg.com (2020).

[22] https://finance.yahoo.com (2020). 